\title{
Distributional evidence and threats to cheer pheasant (Catreus wallichii) in Annapurna Conservation Area, Nepal
}

\author{
Nar Bahadur Chhetri ${ }^{1}$ (I) $\mid$ Bijaya Dhami ${ }^{2}$ (I) | Bijaya Neupane ${ }^{2 *}$ (i) | Bipana Maiya Sadadev ${ }^{2}$ (I) $\mid$ Nabaraj
}

\author{
Thapa $^{3}$ \\ ${ }^{1}$ Ministry of Industry, Tourism, Forest and Environment, Karnali Province, Surkhet, Nepal \\ ${ }^{2}$ Pokhara Campus, Institute of Forestry, Tribhuvan University, Pokhara, Nepal \\ ${ }^{3}$ Schools of Forestry and Natural Resource Management, Tribhuvan University, Kathmandu, Nepal \\ *Correspondence: bijneu@gmail.com
}

Received: 28 September 2020 | Revised: 03 November 2020 | Accepted: 10 November 2020

\begin{abstract}
Cheer pheasant, a vulnerable species in the pheasant family, Phasianidae, is found distributed through the southern foothills of the Himalayas from Pakistan to Nepal. In Nepal, it has been recorded from few areas including the Annapurna Conservation Area (ACA) in central Nepal. However, no systematic survey has been conducted on this shy species in the ACA since 2010. Thus, this study represents a general picture of cheer pheasant distribution and potential threats in Lete and Kunjo Rural Municipalities of Mustang district within the ACA by establishing vantage points in different locations. Among ten vantage stations, cheer pheasants were detected from all stations in Kunjo but only from three stations in Lete. The major threats to the species were found to be overgrazing, habitat fragmentation and hunting/snaring. For the effective conservation of cheer pheasants, a conservation program should be promptly formulated and implemented in Mustang district.
\end{abstract}

Keywords: Cheer pheasant, Habitat fragmentation, Snaring, Vantage, Vulnerable birds

\section{1 | Introduction}

Cheer pheasant (Catreus wallichii) (hereafter- cheer) is a medium sized bird belonging to the order Galliformes and family Phasianidae. It weighs about 1250-1700 gram (Jolli et al. 2012). Cheer breeds during spring season. They produce irregular and sporadic call especially at dawn (Ali \& Ripley 1987). Cheer is listed as vulnerable by IUCN (Birdlife International 2017) and as endangered species in Nepal (Inskipp et al. 2016). It is scheduled as a protected species among the nine bird species in the National Parks and Wildlife Conservation (NPWC) Act 1973 of Nepal and included in Appendix I by the Convention on International Trade in Endangered Species of Wild Fauna and Flora (CITES) (DNPWC 2020). The species occurs all through the southern lower regions of the western Himalayas, in northern Pakistan, India and central Nepal (Birdlife International 2014). It is a local inhabitant in western Nepal in elevations ranging from 1445 to $3050 \mathrm{~m}$. In previous studies, it has been recorded from
Dhorpatan Hunting Reserve, lower Kali Gandaki valley of Annapurna Conservation Area (ACA), Rara National Park, Api Nampa Conservation Area, and districts such as Baitadi, Doti, Jumla, Mugu, Achham and Dolpa (DNPWC 2020).

Cheer inhabits sharp, rough rocky territories dominated by scrub, tall grasses and dissipated clusters of trees (Bisht et al. 2007). It is mostly observed in regenerating coniferous and broadleaved forests, with tree species such as Juniper, Rhododendron and on the grassy inclines (Subedi 2003). Cheer feeds on vegetative and non-vegetative diets relying upon their accessibility in nature. It pokes and searches for roots and tubers, and even eats seeds, berries, insects and grubs (Ali \& Ripley 1987).

The population of cheer is naturally fragmented because it inhabits in small patches of successional grasslands (Basnet \& Poudyal 2017). Snaring and hunting, overgrazing, deforestation and uncontrolled forest fire have been identified as the major threats to cheer in Nepal (Subedi 2003, Singh et al. 2006, 2011, Inskipp et al. 2016). Due to these anthropogenic pressures, the 
population of the cheer is in a decreasing trend, with an estimated global population of $2000-2700$ individuals (Bird Life International 2017). Similarly, the population size in Nepal was estimated to be less than 1000 individuals (Inskipp et al. 2016).

The population of cheer is declining at an alarming rate from its distributional ranges in Nepal. A study carried by Subedi (2009) estimated that there were 25-37 individuals in Kali Gandaki valley of Mustang district which lies in the ACA region and also suggested more studies on the anthropogenic pressure in the potential cheer habitats. Basnet and Poudyal (2017) suggested that further studies have to be undertaken in potential habitat to protect the remaining population of this globally vulnerable bird species. Hence, we aimed to find out the distribution and potential threats to cheer in Lete and Kunjo Rural municipalities of Mustang district, Nepal.

\section{2 | Materials and methods}

\section{1 | Study area}

This study was conducted in lower Kali Gandaki watershed area, which lies in Mustang district of ACA (Fig. 1) focusing two rural municipalities, Lete and Kunjo, which spread from 2300 m to 3200 $\mathrm{m}$ above the sea level. The ACA is the largest protected area of $\mathrm{Nepal}$, located in the western region $\left(28.325^{\circ} \mathrm{N}, 84.397^{\circ} \mathrm{E}\right.$ to $28.603^{\circ} \mathrm{N}, 84.455^{\circ} \mathrm{E}$ and $29.235^{\circ} \mathrm{N}, 83.772^{\circ} \mathrm{E}$ to $28.482^{\circ} \mathrm{N}$, $83.648^{\circ} \mathrm{E}$ ), and covers an area of $7629 \mathrm{~km}^{2}$ (NTNC 2013; DNPWC 2017). It comprises a wide range of habitats, from subtropical forest to Alpine tundra. It provides habitat for important faunal species such as Himalayan musk deer (Moschus leucogaster), red panda (Ailurus fulgens), snow leopard (Panthera uncia), lynx (Felis lynx), Himalayan brown bear (Ursus arctos), blue sheep (Pseudois nayaur), Tibetan argali (Ovis ammon), grey wolf (Canis lupus), leopard cat (Prionailurus bengalensis), Himalayan monal (Lophophorus impejanus), satyr tragopan (Tragopan satyra) and cheer pheasant (Catreus wallichii) (KMTNC 1997, Inskipp \& Inskipp 2003, DNPWC 2017). There are temperate and sub-alpine forests, a suitable habitat for Cheer Pheasant (Inskipp \& Inskipp 2003). 'Thakalis' are the main ethnic group of this area and their main occupation is tourism, animal husbandry and agriculture.

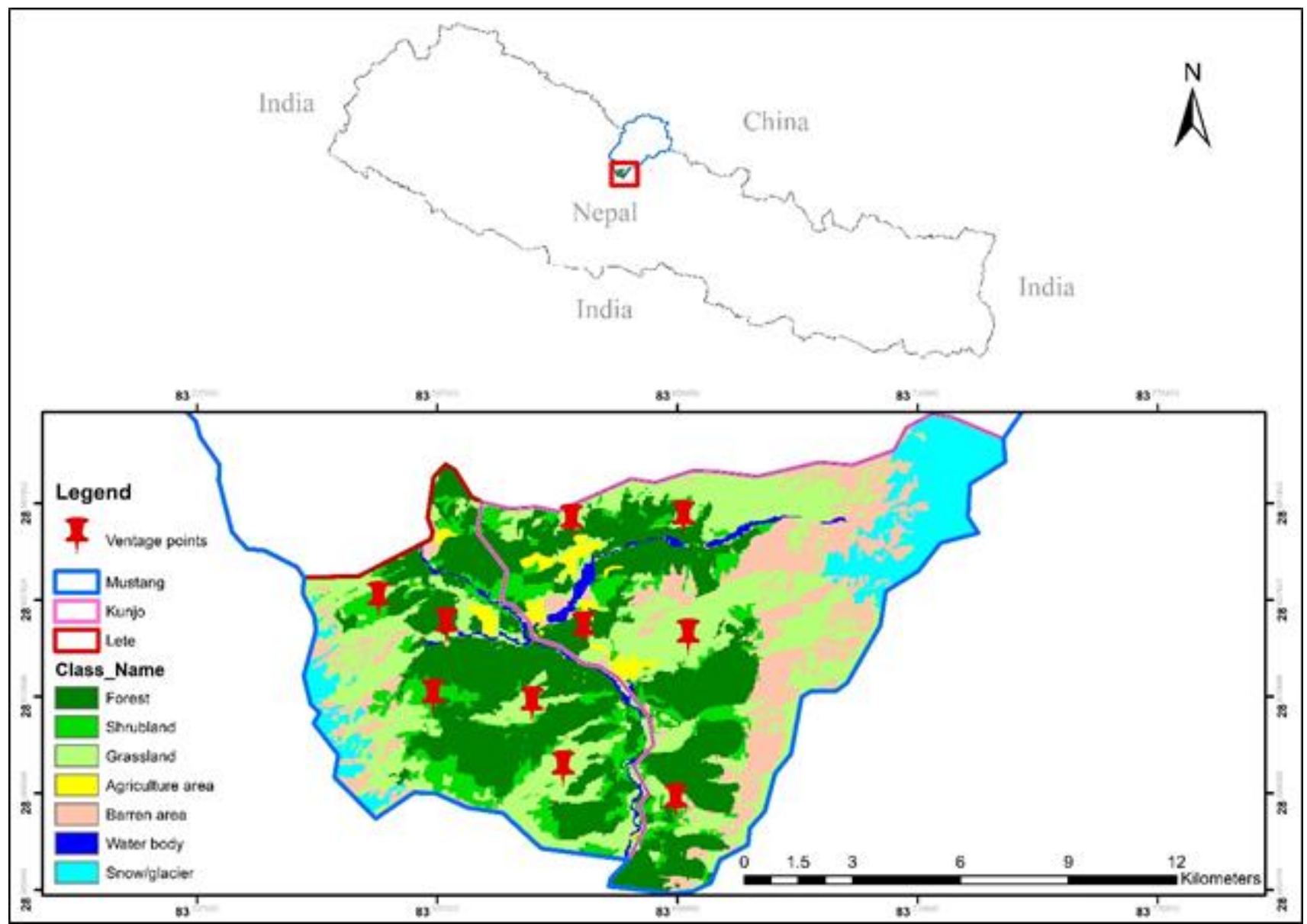

Figure 1. Study area including Lete and Kunjo Rural Municipalities 


\section{2 | Data collection}

\section{Establishment of vantage points and cheer survey}

The potential habitats of cheer were initially identified through preliminary field visit and discussions with local people of Mustang district who were mostly herders. Based on the signs observed during the preliminary field visit and discussion with local people, two rural municipalities i.e. Kunjo and Lete of Mustang district were selected as research sites and five vantage points (Garson 1998) were established on each site. Cheers were detected either by their call or by direct sightings. The presence-absence survey was used for recording the cheer calls (Jolli et al. 2012, MacKenzie et al. 2006). The sites were visited two times a day (morning 05:00 hrs to 07:00 hrs and evening 16:00 hrs to 18:00 hrs) for ten days during the breeding season in June 2016. Circular plots each of $300 \mathrm{~m}$ in radius were set $500 \mathrm{~m}$ apart on each station as listening plots to avoid a double count. The apparent positions of all calling individuals were plotted on a datarecording sheet following the protocols that have been used in other similar studies of the Himalayan pheasants (e.g. MacKenzie et al. 2002, Jolli \& Pandit 2011). If no calls were heard, cheer playback calls downloaded from (https://www.xeno-canto.org) were played for 60 seconds to elicit responses of cheer. Playback calls are quite useful in presence-absence surveys particularly in difficult terrain (Garson 1998; Awan et al. 2004). It was assumed that every observer identified the cheer calls correctly. Thus, two observers were deployed for call identification and recording Each call was recorded with respect to cardinal direction, and the GPS coordinates recorded were displayed in ArcGIS 10.3.

\section{Transect walk}

Transect walks were conducted on the sites $(50 \mathrm{~m}$ effective distance) where there were no vantage points to find out the presence of cheer on other locations within the study area (Acharya 2004). A guide to Birds of Nepal (Inskipp \& Inskipp 1985) was referred for the taxonomic confirmation of cheer that was sighted directly during the field survey. For the confirmation of call, short calls of cheer downloaded from the internet were played using an audiocassette. Presence of body parts such as feathers were also used as evidence for the occurrence of the cheer.

\section{Threat assessment}

Initially nine key informant surveys (6 NTNC staffs, 3 bird guides) were conducted to introduce the conservation threats which were further ranked through the relative threat ranking method (WWF 2007) trailed by Kafle et al. (2020) and Neupane et al. (2020). Three criteria with scope, severity, and urgency were utilized to understand and decide the major existing threats, which were ranked on the basis of the collected data.

Table 1. Scale of classification for scope, severity and urgency of threats.

\begin{tabular}{|c|c|c|c|}
\hline Threat category & Scale & Classification & Definition \\
\hline \multirow[t]{4}{*}{ Scope } & 4 & Very high & The threat that is probably going to influence the target over all or most $(71-100) \%$ of populace. \\
\hline & 3 & High & The threat that is probably going to influence the target over much $(31-70) \%$ of populace. \\
\hline & 2 & Medium & The threat that is probably going to influence the target over some $(11-30) \%$ of populace. \\
\hline & 1 & Low & The threat that is probably going to influence the target over small proportion (1-10) \% of populace. \\
\hline \multirow[t]{4}{*}{ Severity } & 4 & Very high & $\begin{array}{l}\text { Within the scope, the threat is probably going to demolish, banish or diminish the populace by } 71-100 \% \\
\text { in the following } 10 \text { years }\end{array}$ \\
\hline & 3 & High & $\begin{array}{l}\text { Within the scope, the threat is probably going to seriously diminish the populace by } 31-70 \% \text { in the } \\
\text { following } 10 \text { years }\end{array}$ \\
\hline & 2 & Medium & $\begin{array}{l}\text { Within the scope, the threat is probably going to moderately diminish the populace by } 11-30 \% \text { in the } \\
\text { following } 10 \text { years }\end{array}$ \\
\hline & 1 & Low & $\begin{array}{l}\text { Within the scope, the threat is probably going to slightly diminish the populace by } 1-10 \% \text { in the following } \\
10 \text { years }\end{array}$ \\
\hline \multirow[t]{4}{*}{ Urgency } & 4 & Very high & $\begin{array}{l}\text { The impacts of the threat can't be over turned, it's impossible the target can be reestablished and will } \\
\text { take over } 100 \text { years to do it }\end{array}$ \\
\hline & 3 & High & The impacts of the threat can be over turned and the target reestablished inside $21-100$ years \\
\hline & 2 & Medium & The impacts of the threat can be over turned and the target reestablished inside $6-100$ years \\
\hline & 1 & Low & The impacts of the threat are easily reversible and the target reestablished inside $0-5$ years \\
\hline
\end{tabular}




\section{3 | Data analysis}

ArcGIS 10.3 was used to prepare the spatial distribution map of cheer based on the recorded GPS coordinates on each presence locations. Further, from the areas where cheers were recorded, five sorts of major threats (Table 3 ) were identified during the site visit and were assigned a relative rank from high (5) to low (1) based up on the criterion of WWF (2007) as shown in Table 1. Finally, it was further reclassified into four categories as Very high, High, Medium and Low.

\section{3 | Results}

\section{1 | Distribution of cheer}

Three cheers were sighted on three sites and their calls were heard on five sites. Among 10 predetermined call stations, cheer was detected from all five stations in Kunjo but were not detected from Thulachaur and Lete Paari sites in Lete (Table 2). Most of the calls $(\mathrm{N}=4)$ were heard between $04: 45 \mathrm{hrs}$ to $05: 15 \mathrm{hrs}$ with some occasional calls at 15:00 hrs. The birds were seen between 05:40 hrs and 05:50 hrs in the morning and between 17:30 hrs

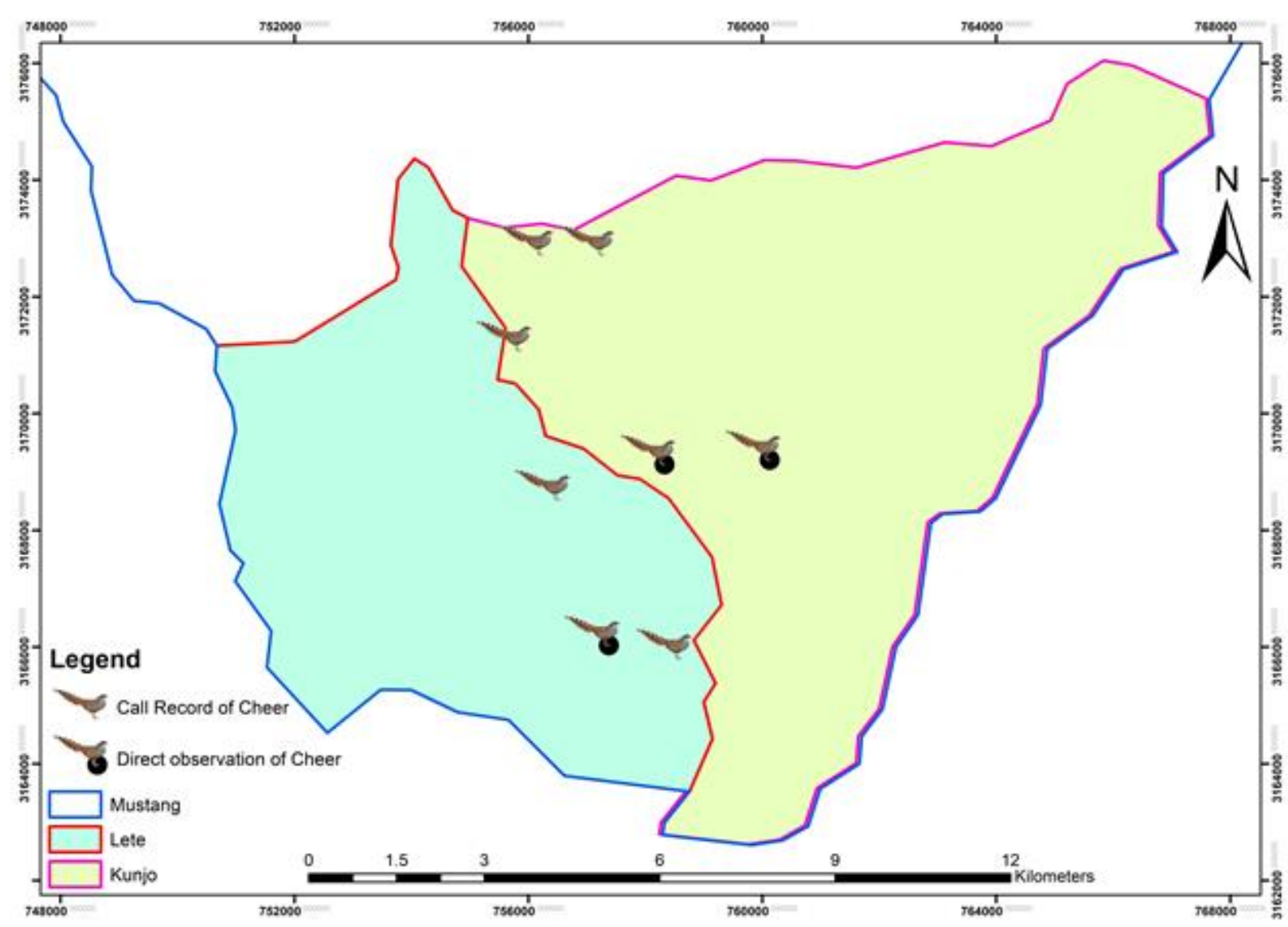

Figure 2. Distribution of cheer pheasant in Lete and Kunjo
Table 2. Presence and absence of cheer in Lete and Kunjo

\begin{tabular}{|c|c|c|c|}
\hline $\begin{array}{l}\text { Rural } \\
\text { Municipalities }\end{array}$ & Locations & $\begin{array}{l}\text { Means of } \\
\text { Verification }\end{array}$ & Remarks \\
\hline \multirow{5}{*}{ Lete } & Thulachaur & Not found & -ve Site \\
\hline & Missi (Bunga Dobhan) & Call recorded & +ve site \\
\hline & Ghasa (Thulo mela) & Direct observation & +ve site \\
\hline & Chipchipe Khola & Call recorded & +ve site \\
\hline & Lete Paari & Not found & -ve site \\
\hline \multirow{5}{*}{ Kunjo } & Titi & Call recorded & +ve site \\
\hline & Kunjo (Seto Bheer) & Call recorded & +ve site \\
\hline & Phudar & Direct observation & +ve site \\
\hline & Paaniko Kuwa & Direct observation & +ve site \\
\hline & Ghasa Paari & Call recorded & +ve site \\
\hline
\end{tabular}

and 17:45 hrs in the evening. Also, the cheers were mostly distributed to the east and north of the Kaligandaki River (Fig. 2).

\section{2 | Threats to cheer}

Our results suggest that over grazing and habitat fragmentation were the critical threats to the cheer. Human population pressure was ranked as high threat, whereas, hunting and snaring were ranked as medium threat, and forest fire was regarded as low threat to cheer (Table 3). 


\section{4 | Discussion}

According to Acharya et al. (2006), cheer was confirmed occurring four kilometers (Aerial distance) east of Kali Gandaki valley in the Pudhar Kharka area $\left(28^{\circ} 37^{\prime} 30.1^{\prime \prime} \mathrm{N} 083^{\circ} 39^{\prime} 53.2^{\prime \prime E}\right.$, at $2660 \mathrm{~m}$ altitude) of Kunjo Rural Municipality. There were scattered chirpine trees (Pinus roxburghii) in the area where cheers were detected. This is likely because chir-pine serves as a roosting site for cheer at night (Hushangabadkar \& Anwar 2019).

Table 3. Relative threat ranking

\begin{tabular}{|r|l|l|l|l|l|l|}
\hline $\mathbf{S}$ & Threat & Scope & Severity & Urgency & Total & Category \\
\hline $\mathbf{1}$ & Over grazing & 4 & 5 & 5 & 14 & VH \\
\hline $\mathbf{2}$ & Forest fire & 1 & 1 & 1 & 3 & L \\
\hline $\mathbf{3}$ & $\begin{array}{l}\text { Population } \\
\text { Pressure }\end{array}$ & 2 & 3 & 3 & 8 & H \\
\hline $\mathbf{4}$ & Hunting and & 3 & 2 & 2 & 7 & M \\
\hline $\mathbf{5}$ & $\begin{array}{l}\text { Habitat } \\
\text { snaring }\end{array}$ & 5 & 4 & 4 & 13 & VH \\
\hline & Total & 15 & 15 & 15 & 45 & \\
\hline
\end{tabular}

Livelihood of most of the people of Kunjo and Deurali is dependent on animal husbandry. Each of the household has a number of cattle, goats and sheep. Shepherds and local from same village used forest grassland for animal grazing in Kunjo, which they claim to be their birthright. They have been using the grasslands for animal grazing since ancient times. Due to the grazing pressure, the habitat of cheer seems to be shifting to the less disturbed non-grazed areas. So, intense and increased grazing can be regarded as a threat for the cheer (Rahmani 2012). Similarly, Dhami et al. (2020) accounted habitat degradation and fragmentation as threats to birds in Nepal, while Iftikhar et al. (2017) reported it as major threat for cheer. This species appears to be distributed in small isolated populations. Madge and McGowan (2002) and Rahmani (2012) have documented that growing human population has impeded the increase in population of cheers in the wild.

People living in 160 households of Kunjo and 125 households of Lete have direct and indirect dependency with the cheer's habitat. Grass cutting, collection of bamboo shoots and collection of medicinal plant on those sites are common phenomena. People and cheers have to adjust on the same area for their survival, which increases the interspecific competition in the area. Likewise, hunting and snaring have been reported as major threats to cheer (Budha 2006). Local people mostly children from near villages use the catapult to hunt cheer for meat. When livestock herders find the nest of the bird, they used to snatch the eggs. Besides, uncontrolled forest fires have been one of the threats to cheer (Subedi 2003). Each year, local herders set fire to the grazing areas expecting new shoots of grass to arise so that their animals get fresh and nutritious grass for grazing. These fires destroy the preferred habitat and food of cheer. Bamboo and khar grass, which are major vegetation types of the area, are highly susceptible to fire.

\section{5 | Conclusions}

Out of the ten pre-identified call stations, cheers were directly observed on three call stations. The main population was distributed to the east and north of the Kaligandaki River. Phudar, Ghasha and Paani Kuwa were good sites for watching the cheer. The main habitat threats for cheer were annual burning of grasslands, increased grazing at limited areas, hunting and snaring by children and herders. Similarly, population pressure and forest succession were posing threats to the habitat of cheer. To protect the cheer and their habitat, an effective conservation program should be formulated and implemented soon at the local level.

\section{Acknowledgements}

We would like to express our deep gratitude to Suman Bhattarai, Tribhuvan University, Institute of Forestry, Pokhara, Nepal for instrumental and moral support. We would like to thank Annapurna Conservation Area, Unit Conservation Office, Mustang and local people including field assistants for their contributions during the fieldwork.

\section{Authors' contributions}

Chhetri, N. B. conceptualized the study, collected and analyzed data; Dhami, B. performed GIS analysis and prepared manuscript; Sadadev, B. M prepared manuscript; Neupane, B. and Thapa, N. contributed critically in finalizing the draft.

\section{Conflicts of interest}

Authors declare no conflict of interest.

\section{ORCID}

Nar Bahadur Chhetri iD https://orcid.org/0000-0002-0903-5723

Bijaya Dhami (D) https://orcid.org/0000-0002-4127-138X

Bijaya Neupane (D) https://orcid.org/0000-0003-1215-689X 
Bipana Maiya Sadadev (iD https://orcid.org/0000-0001-9162-2398 Nabaraj Thapa iD https://orcid.org/0000-0003-0490-6865

\section{References}

Acharya, R. 2004. Survey of the cheer pheasant (Catreus wallichii) (Hardwicke, 1827) in lower Kali Gandaki valley, Mustang, Nepal. Report to King Mahendra Trust for Nature Conservation, Annapurna Conservation Area Project, Nepal; World Pheasant Association, UK; School of Environmental Management and Sustainable Development, Nepal. Unpublished. p 43.

Acharya, R. S, Thapa, S. and Ghimirey, Y. 2006. Monitoring of the cheer pheasant Catreus wallichii in lower Kaligandaki valley, Mustang, Nepal. Report to King Mahendra Trust for Nature Conservation, Annapurna Conservation Area Project, Nepal; World Pheasant Association, UK; School of Environmental Management and Sustainable Development, Nepal, p 43.

Ali, S. and Ripley, S. D. 1987. Compact handbook of the birds of India and Pakistan. Oxford University Press, Delhi, p 104

Awan, M. S., Khan, A. A., Ahmad, K. B., Qureshi, M. A., Malik, M. A. and Dar, N. I. 2004. Population Dynamics of Cheer Pheasant in Jhelum Valley, Muzaffarabad, Azad Kashmir, Pakistan. Pakistan Journal of Biological Science 7:789-796.

Basnet, H. and Poudyal. L.P. 2017. Review on distribution of cheer pheasant in Nepal. Danphe 26(2):1-5.

BirdLife International. 2014. Catreus wallichii. The IUCN Red List of Threatened Species 2014:e.T22679312A62707859. http://dx.doi.org/10.2305/IUCN.UK.20142.RLTS.T22679312A627 07859.en Accessed on 14 June /2020.

BirdLife International. 2017. Catreus wallichii (amended version of 2016 assessment). The IUCN Red List of Threatened Species 2017 e.T22679312A112455142.

https://dx.doi.org/10.2305/IUCN.UK.2017-1.RLTS.T22679312A11 2455142.en. Downloaded on 15 June 2020

Bisht, M. S., Phurailatpam, S., Kathait, B. S., Dobriyal, A. K., ChandolaSaklani, A., and Kaul, R. 2007. Survey of threatened cheer pheasant Catreus wallichi in Garhwal Himalaya. Journal of the Bombay Natural History Society 104(2):134-139.

Budha, P. B. 2006. The Cheer Pheasant Catreus wallichii (Hardwicke, 1827) and indigenous hunting techniques in mid and far west Nepal. Danphe 15(2/3):2-3.

Dhami, B., Sadadev, B. M., Thapa, N., Bista, S., Rawat, Y. B. Neupane, B., and Gautam, D. 2020. Exploring distributional evidences and threats to initiate conservation of Great Hornbil (Buceros bicornis) In Nepal. Archives of Agriculture Research and Technology 1(3):1011.
DNPWC. 2017. Protected areas of Nepal [in Nepali]. Department of National Parks and Wildlife Conservation. Kathmandu, Nepal. p 97.

DNPWC. 2020. Cheer Pheasant. Department of National Parks and Wildlife Conservation. http://dnpwc.gov.np/en/species-detail/48/, Accessed on $2020 / 10 / 22$.

Garson, P. J. 1998. Conservation of Galliformes in the Great Himalayan National Park: A Review of Monitoring and Research Activity. Department of Agricultural and Environmental Science, University of Newcastle, Newcastle upon Tyne, U.K., pp 1-19.

Hushangabadkar, P. and Anwar, M. 2019. Cheer Pheasant Catreus wallichii: a new low altitude record from Nandhaur Wildlife Sanctuary, Uttarakhand, India. Birding Asia 31:65-67.

Iftikhar, N., Qamar, Q. Z., Ali, U., Awan, M. S., Bibi, S. S. and Minhas, R. A. 2017. Population status of Cheer Pheasant (Catreus wallichii) in Azad Jammu and Kashmir, Pakistan. Punjab University Journal of Zoology 32(1):101-109.

Inskipp C., Baral H. S., Phuyal S., Bhatt T. R., Khatiwada M., Inskipp, T, et al. 2016. The status of Nepal's Birds: The national red list series. Zoological Society of London, UK, p 628.

Inskipp, C. and Inskipp, T. 1985. A guide to the Birds of Nepal. Dover, New Hampshire, Tanager Books, p 392.

Inskipp, C. and Inskipp, T. 2003. Bird conservation priorities of the Annapurna Conservation Area, s.I.: Report submitted to UNEPWCMC/King Mahendra Trust for Nature Conservation / Annapurna Conservation Area Project, p 72.

Jolli, V., Srivastav, A. and Thakur, S. 2012. Patch occupancy for cheer pheasant Catreus wallichii in the Great Himalayan National Park Conservation Area. International Journal of Galliformes Conservation 2:74-81.

Jolli, V. and Pandit, M. 2011. Influence of human disturbance on the abundance of Himalayan pheasant (Aves, Galliformes) in the temperate forest of Western Himalaya, India. Vestnik zoologii 45(6):e-40. http://dx.doi.org/10.2478/v10058-011-0035-0

Kafle, K., Thanet, D. R, Poudel, P., Gautam, D., Thapa, G. and Bhatt, P. 2020. Status and conservation threats to large mammals of the Laljhadi Mohana Biological Corridor, Nepal. Journal of Animal Diversity 2(2):16-33. http://dx.doi.org/10.29252/JAD.2020.2.2.3

KMTNC. 1997. Biodiversity database of Annapurna conservation area. Biodiversity database project. Lalitpur, Nepal, National Trust for Nature Conservation, p 23-24.

MacKenzie, D. I., Nichols, J. D., Royle, J. A., Pollock, K. H., Bailey, L. L. and Hines, J. E. 2006. Occupancy estimation and modeling: inferring patterns and dynamics of species occurrence. Academic Press, USA, p 324.

MacKenzie, D. I., Nichols, J. D., Lachman, G. B., Droege, S., Andrew Royle, J., et al. 2002. Estimating site occupancy rates when 
detection probabilities are less than one. Ecology 83(8):2248-

2255. https://doi.org/10.1890/0012-9658(2002)083

Madge, S., and Mcgowan, P. 2002. Pheasants, Partridges and Grouse Including Buttonquails, Sandgrouse and Allies (Helm Identification Guides). Bloomsbury Publishing PLC, London, United Kingdom, p 408.

Neupane, B., Singh, B. K., Poudel, P., Panthi, S., and Khatri, N. D. 2020. Habitat occupancy and threat assessment of gharial (Gavialis gangeticus) in the Rapti River, Nepal. Global Ecology and Conservation 24:e01270. https://doi.org/10.1016/j.gecco.2020.e01270

NTNC. 2013. National Trust for Nature Conservation. Annual Report. Lalitpur, Kathmandu, p 57.

Rahmani, A. R. 2012. Threatened birds of India: their conservation requirements. Oxford University Press, Mumbai, p 864.

Singh, P. B. 2009. Cheer pheasant in peril in Rara National Park, Nepal. The International Newsletter of World Pheasant Association, Fordingbridge, UK, $\mathrm{p} 83$.

Singh, P. B., Paudyel, L. and Sharma, S. 2006. Survey of cheer pheasant Catreus wallichi in and around Dhorpatan Hunting Reserve, Western Nepal. Report to World Pheasant Association, UK \& Oriental Bird Club, UK, p 30.

Singh, P. B., Subedi, P., Garson, P. J. and Poudyal, L. 2011. Status, habitat use and threats of cheer pheasant Catreus wallichi in and around Dhorpatan Hunting Reserve, Nepal. International Journal of Galliformes Conservation 2:22-30.

Subedi, P. 2003. Status and distribution of Cheer Pheasant Catreus wallichi in Dhorpatan Hunting Reserve, Nepal. Unpublished report submitted to World Pheasant Association and Oriental Bird Club.

Subedi P. 2009. Monitoring of Cheer Pheasant (Catreus wallichii) in Kaligandaki River Valley, Mustang District, Nepal. A research report submitted to National Trust for Nature Conservation / Annapurna Conservation Area Project, Unit Conservation Office, Jomsom, Nepal, p 41.

WWF. 2007. Resources for implementing the WWF project \& programme standards, define: threat Ranking.

https://wwf.panda.org. Accessed on 2020/10/16.

\section{Cite this article as:}

Chhetri, N. B., Dhami, B., Neupane, B., Sadadev, B. M. and Thapa, N. 2020. Distributional evidence and threats to cheer pheasant (Catreus wallichii) in Annapurna Conservation Area, Nepal. Nepalese Journal of Zoology 4(2):140-146. https://doi.org/10.3126/njz.v4i2.33906 